\title{
Incidence of hospital admissions and severe outcomes during the first and second waves of pandemic (H1N1) 2009
}

\author{
Melissa Helferty MIPH, Julie Vachon MSc, Jill Tarasuk MSc, Rachel Rodin MD MPH, John Spika MD, \\ Louise Pelletier MD MPH
}

Previously published at www.cmaj.ca

\section{ABSTRACT}

Background: Canada experienced two distinct waves of pandemic (H1N1) influenza during the 2009 pandemic, one in the spring and the second in early fall 2009. We compared the incidence of hospital admissions and severe outcomes (admission to intensive care unit [ICU] and death) during the two waves.

Methods: We reviewed data on all laboratory-confirmed cases of pandemic (H1N1) influenza that resulted in hospital admission, ICU admission or death reported to the Public Health Agency of Canada by all provinces and territories from Apr. 18, 2009, to Apr. 3, 2010.

Results: A total of 8678 hospital admissions (including 1473 ICU admissions) and 428 deaths related to pandemic (H1N1) influenza were reported during the pandemic and post-peak period. There were 4.8 times more hospital admissions, 4.0 times more ICU admissions and 4.6 times more deaths in the second pandemic wave than in the first wave. ICU admissions and deaths as a proportion of hospital admissions declined in the second wave; there was a $16 \%$ proportional decline in ICU admissions and a $6 \%$ proportional decline in deaths compared with the first wave. Compared with patients admitted to hospital in the first wave, those admitted in the second wave were older (median age 30 v. 23 years) and more had underlying conditions (59.7\% v. $47.5 \%)$. Pregnant women and Aboriginal people accounted for proportionally fewer patients who were admitted to hospital or who died in the second wave than in the first.

Interpretation: The epidemiologic features of the first and second waves of the 2009 pandemic differed. The second wave was substantially larger and, although the patients admitted to hospital were older and more of them had underlying conditions, a smaller proportion had a severe outcome.

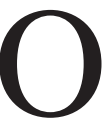
n Apr. 26, 2009, the first six cases of pandemic (H1N1) influenza in Canada were reported: four in Nova Scotia $^{1}$ and two in British Columbia. Most of the initial cases involved travellers returning from Mexico or people epidemiologically linked to these travellers. However, communitybased transmission occurred rapidly, and the virus spread across Canada. By the end of May 2009, more than 1000 laboratoryconfirmed cases of pandemic (H1N1) influenza had been reported in Canada, with introduction of the virus into 12 of the 13 provinces and territories. As of Apr. 3, 2010, Canada had experienced two defined waves of the 2009 pandemic, one in the spring and the second in early fall 2009.

We compared the epidemiologic features of all laboratoryconfirmed cases of pandemic (H1N1) influenza requiring hospital admission and related deaths reported to the Public Health Agency of Canada during the first wave of the pandemic and during the second wave and post-peak period.

\section{Methods}

\section{Population}

We compared demographic and clinical characteristics as well as outcomes of patients with pandemic (H1N1) influenza admitted to hospial during the first wave to those admitted during the second wave and post-peak period of the pandemic. The following definitions ${ }^{2}$ applied throughout the pandemic. A laboratory-confirmed case involved a person with (or without) clinical symptoms whose pandemic (H1N1) influenza was confirmed by reverse transcriptase polymerase chain reaction, viral culture or a four-fold rise in antibodies against the pandemic virus. A hospital admission referred to a person who was admitted to hospital with laboratoryconfirmed pandemic (H1N1) influenza. A death related to pandemic $(\mathrm{H} 1 \mathrm{~N} 1)$ influenza referred to a death of a person with laboratory-confirmed pandemic influenza with no period of complete recovery between illness and death. Probable or suspected cases were not reportable to the Public Health Agency of Canada from the beginning of the pandemic.

\section{Data collection}

All 13 Canadian provinces and territories conducted surveillance for laboratory-confirmed cases and reported them to the Public Health Agency of Canada. For the first few hundred cases, detailed case report forms were completed. As the pandemic unfolded, abbreviated case-based reporting was established with a set of national core variables as well as modifications to the frequency of reporting (Table 1). By mid-July 2009 , only hospital admissions and deaths related to pan-

From the Centre for Immunization and Respiratory Infectious Diseases (Helferty, Vachon, Rodin, Spika, Pelletier) and the Centre for Communicable Diseases and Infection Control (Tarasuk), Public Health Agency of Canada, Ottawa, Ont.

CMAJ 2010. DOI:10.1503/cmaj.100746 
demic influenza were reported on a weekly basis. During the peak of the second pandemic wave, some provinces reported only aggregate counts of hospital admissions and deaths.

\section{Data analysis}

In this report, the first wave of the pandemic in Canada referred to the period from Apr. 12 to Aug. 29, 2009 (the end of week 34,2009 ); the second wave and post-peak period referred to the period from Aug. 30, 2009, to Apr. 3, 2010 (the end of week 13, 2010). All patients admitted to the intensive care unit (ICU) are included in the hospital admission count; however, not all deaths involved patients who had been admitted to hospital.

The national case-based and aggregate databases were the only sources of data for the numerators. Age, sex, and provincial and territorial denominators for population-based rates (per 100 000) were calculated using Statistics Canada's 2009 population estimates. ${ }^{3}$

Demographic and clinical characteristics of the patients were examined across hospital admissions, ICU admissions and deaths in each pandemic wave. The magnitude of the differences between the first and second waves were described.

\section{Results}

Canada experienced two distinct waves during pandemic (H1N1) 2009 (Figure 1). The first wave peaked between May 31 and June 20, 2009, and accounted for $9.4 \%$ of the hospital admissions, $10.1 \%$ of the ICU admissions and $10.0 \%$ of the deaths. The second wave peaked between Oct. 25 and Nov. 14, 2009, and accounted for $51.0 \%$ of the overall hospital admissions, $49.4 \%$ of the ICU admissions and $53.0 \%$ of the deaths (Table 2).

From Apr. 12, 2009, to Apr. 3, 2010, a total of 8678 laboratory-confirmed cases of pandemic (H1N1) influenza requiring admission to hospital (including 1473 [17.0\%] ICU admissions) and $428(4.9 \%)$ deaths related to pandemic (H1N1) influenza were reported (Table 2). Among the 1117 ICU admissions that had detailed information regarding ventilation status, 654 (58.5\%) required ventilation. Among all reported cases, core data were available for 8227 (94.8\%) hospital admissions, 1473 (100\%) ICU admissions and 423 (98.8\%) deaths.

There were 4.8 times more hospital admissions reported in the second wave than in the first wave (7188 v. 1490); 4.0 times more ICU admissions (1181 v. 292) and 4.6 times more deaths (351 v. 77). ICU admissions and deaths as a proportion of hospital admissions declined in the second wave; there was a $16 \%$ proportional decline in ICU admissions (from 19.6\% [292/1490] to $16.4 \%$ [1181/7188]) and a 6\% proportional decline in deaths (from 5.2\% [77/1490] to 4.9\% [351/7188]) compared with the first wave (Table 2).

\section{Geographic distribution}

In the first wave, Manitoba, Quebec and Nunavut experienced the highest incidence rates of hospital admission. Dis-

Table 1: Overview of the collection of data on laboratory-confirmed cases of pandemic (H1N1) influenza during the first wave (Apr. 12 to Aug. 29, 2009) and the second wave and post-peak period (Aug. 30, 2009, to Apr. 3, 2010) of the 2009 pandemic

\begin{tabular}{|c|c|c|c|c|c|}
\hline Variable & April to May 2009 & June 2009 & July 2009 & October 2009 & $\begin{array}{l}\text { November } 2009 \\
\text { to January } 2010\end{array}$ \\
\hline $\begin{array}{l}\text { Frequency } \\
\text { and type of } \\
\text { reporting }\end{array}$ & $\begin{array}{l}\text { Real-time detailed } \\
\text { case-based reporting }\end{array}$ & $\begin{array}{l}\text { Weekly abbreviated } \\
\text { case-based reporting }\end{array}$ & $\begin{array}{l}\text { Weekly abbreviated } \\
\text { case-based reporting }\end{array}$ & $\begin{array}{l}\text { Weekly abbreviated } \\
\text { case-based reporting }\end{array}$ & $\begin{array}{l}\text { Combination of } \\
\text { weekly abbreviated } \\
\text { case-based reporting } \\
\text { and aggregate } \\
\text { reporting (5 provinces } \\
\text { and territories) }\end{array}$ \\
\hline $\begin{array}{l}\text { Information } \\
\text { collected }\end{array}$ & $\begin{array}{l}\text { Detailed case } \\
\text { information: age, sex, } \\
\text { province/territory, } \\
\text { Aboriginal status,* } \\
\text { Aboriginal group, } † \\
\text { clinical presentation, } \\
\text { underlying medical } \\
\text { conditions, pregnancy } \\
\text { status, severity of } \\
\text { illness, vaccine history, } \\
\text { antiviral treatment, } \\
\text { exposure history }\end{array}$ & $\begin{array}{l}\text { Core variables: age, } \\
\text { sex, province/ } \\
\text { territory, Aboriginal } \\
\text { status,* Aboriginal } \\
\text { group, † underlying } \\
\text { medical conditions } \\
\text { (including pregnancy), } \\
\text { date of symptom } \\
\text { onset, date of } \\
\text { specimen collection, } \\
\text { date of hospital } \\
\text { admission, ICU } \\
\text { admission (yes v. no), } \\
\text { date of death }\end{array}$ & $\begin{array}{l}\text { In addition to previous } \\
\text { core variables: reserve } \\
\text { status of Aboriginal } \\
\text { patients, pregnancy } \\
\text { trimester and post- } \\
\text { partum period, need } \\
\text { for ventilation, } \\
\text { categorization of } \\
\text { underlying conditions } \\
\text { (chronic heart disease, } \\
\text { chronic pulmonary } \\
\text { disease [including } \\
\text { asthma], diabetes, } \\
\text { chronic renal disease, } \\
\text { immunosuppression } \\
\text { [including cancer]) }\end{array}$ & $\begin{array}{l}\text { In addition to previous } \\
\text { core variables: date } \\
\text { data reported to } \\
\text { PHAC, registered } \\
\text { Indian, residence in } \\
\text { isolated or remote } \\
\text { community, asthma, } \\
\text { chronic liver disease, } \\
\text { anemia or hemo- } \\
\text { globinopathy, chronic } \\
\text { neurologic disease, } \\
\text { weight, height, } \\
\text { obesity, current } \\
\text { smoker, discharged } \\
\text { from hospital }\end{array}$ & $\begin{array}{l}\text { Core variables and } \\
\text { aggregate counts } \\
\text { (some of the } \\
\text { provinces and } \\
\text { territories later sent } \\
\text { core information on } \\
\text { cases reported in } \\
\text { aggregate) }\end{array}$ \\
\hline
\end{tabular}


ease burden in Saskatchewan was also comparatively high in the first wave, as exhibited by its rates of ICU admission and death (Table 3). Higher levels of transmission were reported during the second wave and post-peak period than during the first wave in all of the provinces and territories except Manitoba and Nunavut; the rate in the first wave was 8.4 times higher in Nunavut and 1.3 times higher in Manitoba. Compared with the first wave, British Columbia, Alberta, the Maritimes, Yukon and the Northwest Territories experienced substantially higher rates of hospital admission during the second wave (Table 3). Overall, Quebec reported by far the most hospital admissions, whereas Ontario reported the most deaths.

\section{Age distribution}

The median ages in both pandemic waves increased with severity of illness. In the first wave, the median age was 23 years for hospital admissions, 37 years for ICU admissions and 51 years for deaths; in the second wave, it was 30 years for hospital admissions, 47 years for ICU admissions and 54 years for deaths.

All age groups had higher rates of pandemic (H1N1) influenza per 100000 in the second wave than in the first wave: 3.8 to 6.5 times higher for hospital admissions, 2.6 to 5.6 times higher for ICU admissions and 1.5 to 6.0 times higher for deaths. The greatest increase in rates of hospital admission occurred among people 45 years of age and older (6.5 times greater in the second wave); the lowest increase occurred among patients aged 5-19 years (3.8 times greater in the second wave). The greatest difference in population-based rates of death between the two waves and the age groups occurred among patients between 45 and 64 years of age (6.0 times greater in the second wave) (Table 3 ).

\section{Sex distribution}

Overall, the population-based incidence rates were similar among men and women (Table 3). During the first pandemic wave, however, females represented $51.4 \%$ of hospital admissions, $57.2 \%$ of ICU admissions and $62.3 \%$ of deaths (Table 2). During the second wave, slightly more males than females were affected, accounting for $50.3 \%$ of all hospital admissions, $50.6 \%$ of ICU admissions and $53.2 \%$ of deaths.

\section{Underlying medical conditions}

The proportion of patients with underlying medical conditions increased with severity of illness during both pandemic waves. In the first wave, they accounted for $47.5 \%$ of patients admitted to hospital, $60.2 \%$ of those admitted to ICU and $73.3 \%$ of those who died; the corresponding proportions in the second wave were $59.7 \%, 73.9 \%$ and $85.5 \%$ (Table 2). The proportion of patients with underlying conditions was significantly higher in the second wave than in the first wave $(p<0.001$ for hospital and ICU admissions, $p=$ 0.013 for deaths).

Chronic pulmonary disease (including asthma) was the most commonly reported underlying medical condition among patients admitted to hospital and those who died in both pandemic waves, varying from $33.7 \%$ to $54.3 \%$. The proportion of patients with diabetes, immunosuppression

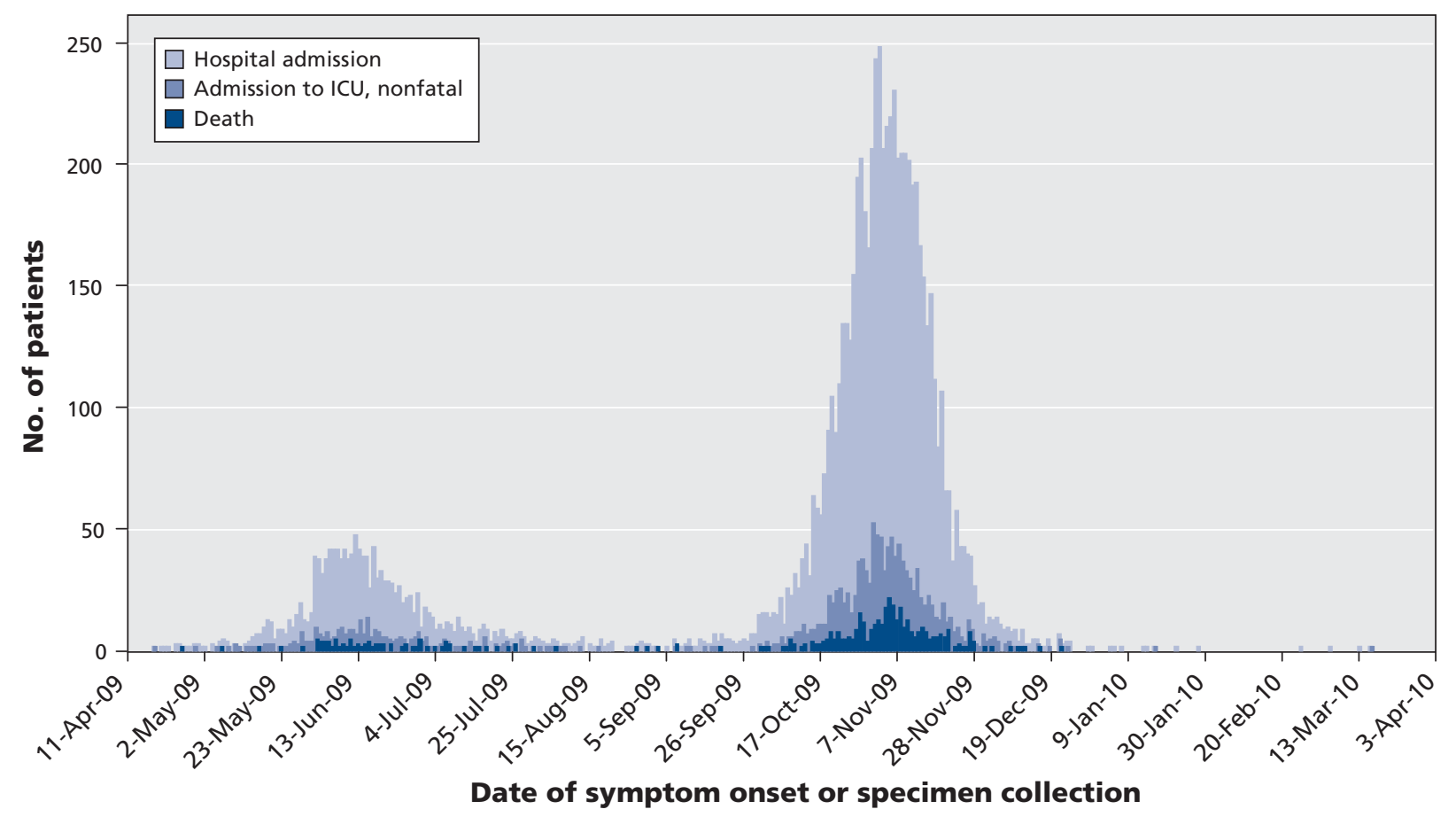

Figure 1: Epidemic curve of laboratory-confirmed cases of pandemic (H1N1) influenza resulting in hospital admission, admission to an intensive care unit (ICU) or death during the first wave (Apr. 12 to Aug. 29, 2009) and the second wave and post-peak period (Aug. 30, 2009, to Apr. 3, 2010) in Canada, by date of symptom onset or collection of specimen. 
(including cancer) and chronic heart disease were relatively similar in both waves and increased by level of severity (hospital admissions: $11.9 \%-12.3 \%$ in the first wave and $15.3 \%-$ $17.4 \%$ in the second wave; deaths: $26.6 \%-34.5 \%$ in the first wave and $32.4 \%-42.4 \%$ in the second wave). Of note, underlying renal disease was reported in $26.2 \%$ of deaths in the second wave, as compared with $11.3 \%$ in the first wave.

\section{Pregnancy}

Of the 272 women of child-bearing age (15-44 years) who were admitted to hospital with pandemic (H1N1) influenza in the first pandemic wave, $75(27.6 \%)$ were pregnant. Pregnant women represented $19.7 \%(15 / 76)$ of those admitted to ICU and $28.6 \%(4 / 14)$ of those who died during that period. In the second wave, fewer women of child-bearing age were preg-

Table 2: Characteristics of 8678 hospital admissions* and 428 deaths related to laboratory-confirmed pandemic (H1N1) influenza reported to the Public Health Agency of Canada during the first wave (Apr. 12 to Aug. 29, 2009) and the second wave and post-peak period (Aug. 30, 2009, to Apr. 3, 2010) of the 2009 pandemic

No. $(\%)$ of patients

\begin{tabular}{|c|c|c|c|c|c|c|c|c|c|}
\hline \multirow[b]{2}{*}{ Characteristic } & \multicolumn{3}{|c|}{ First wave } & \multicolumn{3}{|c|}{ Second wave and post-peak period } & \multicolumn{3}{|c|}{ Total } \\
\hline & $\begin{array}{c}\text { Hospital } \\
\text { admission } \\
n=1490\end{array}$ & $\begin{array}{c}\text { ICU } \\
\text { admission } \\
n=292\end{array}$ & $\begin{array}{l}\text { Death } \\
n=77\end{array}$ & $\begin{array}{c}\text { Hospital } \\
\text { admission } \\
n=7188\end{array}$ & $\begin{array}{c}\text { ICU } \\
\text { admission } \\
n=1181\end{array}$ & $\begin{array}{c}\text { Death } \\
n=351\end{array}$ & $\begin{array}{c}\text { Hospital } \\
\text { admission } \\
n=8678\end{array}$ & $\begin{array}{c}\text { ICU } \\
\text { admission } \\
n=1473\end{array}$ & $\begin{array}{l}\text { Death } \\
n=428\end{array}$ \\
\hline Age, yr & $n=1486$ & $n=292$ & $n=77$ & $n=6732$ & $n=1181$ & $n=346$ & $n=8218$ & $n=1473$ & $n=423$ \\
\hline$<1$ & $129(8.7)$ & 11 (3.8) & $1 \quad(1.3)$ & $461 \quad(6.8)$ & $29(2.5)$ & $5 \quad(1.4)$ & $590 \quad(7.2)$ & $40 \quad(2.7)$ & $6 \quad(1.4)$ \\
\hline $1-4$ & $191(12.9)$ & $19(6.5)$ & 0 & $967(14.4)$ & $55 \quad(4.7)$ & $3(0.9)$ & $1158(14.1)$ & $74 \quad(5.0)$ & $3(0.7)$ \\
\hline $5-19$ & $365(24.5)$ & $45(15.4)$ & $9(11.7)$ & $1283(19.1)$ & 115 (9.7) & $13(3.8)$ & $1648(20.0)$ & $160(10.9)$ & $22 \quad(5.2)$ \\
\hline $20-44$ & $374(25.2)$ & $99(33.9)$ & $19(24.7)$ & $1488(22.1)$ & $326(27.6)$ & $76(21.7)$ & $1862(22.7)$ & $425(28.9)$ & $94(22.2)$ \\
\hline $45-64$ & $308(20.7)$ & $92(31.5)$ & $27(35.0)$ & $1865(27.7)$ & $514(43.5)$ & $160(46.2)$ & $2173(26.4)$ & $606(41.1)$ & $187(44.2)$ \\
\hline$\geq 65$ & $119(8.0)$ & $26 \quad(8.9)$ & $21(27.3)$ & $668 \quad(9.9)$ & $142(12.0)$ & $90(26.0)$ & $787 \quad(9.6)$ & 168 (11.4) & 111 (26.3) \\
\hline \multirow[t]{2}{*}{ Sex, female } & $n=1489$ & $n=292$ & $n=77$ & $n=6731$ & $n=1181$ & $n=346$ & $n=8220$ & $n=1473$ & $n=423$ \\
\hline & 766 (51.4) & $167(57.2)$ & $48(62.3)$ & 3343 (49.7) & $584(49.4)$ & $162(46.8)$ & $4109(50.0)$ & 751 (51.0) & $210(49.6)$ \\
\hline \multirow[t]{2}{*}{ Aboriginal } & $n=1074$ & $n=215$ & $n=51$ & $n=5017$ & $n=889$ & $n=237$ & $n=6091$ & $n=1104$ & $n=288$ \\
\hline & $299(27.8)$ & 47 (21.9) & 9 (17.6) & $308 \quad(6.1)$ & $68 \quad(7.6)$ & $21 \quad(8.9)$ & $607(10.0)$ & $115(10.4)$ & $30(10.4)$ \\
\hline \multirow{2}{*}{$\begin{array}{l}\text { Underlying } \\
\text { medical } \\
\text { condition }\end{array}$} & $n=1374$ & $n=269$ & $n=75$ & $n=3299$ & $n=924$ & $n=289$ & $n=4673$ & $n=1193$ & $n=364$ \\
\hline & $653(47.5)$ & $162(60.2)$ & $55(73.3)$ & $1969(59.7)$ & 683 (73.9) & $247(85.5)$ & $2622(56.1)$ & $845(70.8)$ & $302(83.0)$ \\
\hline \multirow[t]{2}{*}{ Pregnancy $\dagger$} & $n=272$ & $n=76$ & $n=14$ & $n=1028$ & $n=181$ & $n=36$ & $n=1300$ & $n=257$ & $n=50$ \\
\hline & 75 (27.6) & 15 (19.7) & $4(28.6)$ & $191(18.6)$ & $17 \quad(9.4)$ & 0 & $266(20.5)$ & $32(12.5)$ & $4 \quad(8.0)$ \\
\hline $\begin{array}{l}\text { Province/ } \\
\text { territory }\end{array}$ & $n=1490$ & $n=292$ & $n=77$ & $n=7188$ & $n=1181$ & $n=351$ & $n=8678$ & $n=1473$ & $n=428$ \\
\hline $\begin{array}{l}\text { British } \\
\text { Columbia }\end{array}$ & 49 (3.3) & $19 \quad(6.5)$ & $5 \quad(6.5)$ & 1035 (14.4) & $149(12.6)$ & $52(14.8)$ & $1084(12.5)$ & 168 (11.4) & $57(13.3)$ \\
\hline Alberta & $129(8.7)$ & $29 \quad(9.9)$ & $7 \quad(9.1)$ & $1147(16.0)$ & $210(17.8)$ & $64(18.2)$ & 1276 (14.7) & $239(16.2)$ & 71 (16.6) \\
\hline Saskatchewan & $23(1.5)$ & $12(4.1)$ & $4 \quad(5.2)$ & $44 \quad(0.6)$ & $40 \quad(3.4)$ & 11 (3.1) & $67 \quad(0.8)$ & $52 \quad(3.5)$ & $15 \quad(3.5)$ \\
\hline Manitoba & $213(14.3)$ & $43(14.7)$ & $7 \quad(9.1)$ & $166 \quad(2.3)$ & $18 \quad(1.5)$ & $4 \quad(1.1)$ & $379 \quad(4.3)$ & $61 \quad(4.1)$ & 11 (2.6) \\
\hline Ontario & $399(26.8)$ & $69(23.7)$ & $25(32.5)$ & $1444(20.1)$ & $250(21.2)$ & $103(29.4)$ & $1843(21.2)$ & 319 (21.7) & $128(29.9)$ \\
\hline Quebec & $572(38.4)$ & $104(35.6)$ & $27(35.0)$ & 2491 (34.7) & $361(30.6)$ & $81(23.1)$ & $3063(35.3)$ & 465 (31.6) & $108(25.3)$ \\
\hline New Brunswick & $2(0.1)$ & $1 \quad(0.3)$ & 0 & $161 \quad(2.2)$ & $33 \quad(2.8)$ & $8 \quad(2.3)$ & $163(1.9)$ & $34 \quad(2.3)$ & $8 \quad(1.9)$ \\
\hline Nova Scotia & 17 (1.1) & $8 \quad(2.8)$ & 1 (1.3) & $276 \quad(3.8)$ & $42 \quad(3.5)$ & $6(1.7)$ & $293 \quad(3.4)$ & $50 \quad(3.4)$ & $7 \quad(1.6)$ \\
\hline $\begin{array}{l}\text { Prince Edward } \\
\text { Island }\end{array}$ & $1 \quad(0.1)$ & 0 & 0 & $49 \quad(0.7)$ & $9 \quad(0.8)$ & 0 & $50 \quad(0.6)$ & $9 \quad(0.6)$ & 0 \\
\hline $\begin{array}{l}\text { Newfoundland } \\
\text { and Labrador }\end{array}$ & $3 \quad(0.2)$ & $1 \quad(0.3)$ & 0 & $305 \quad(4.3)$ & $59 \quad(5.0)$ & $18 \quad(5.1)$ & 308 & $60 \quad(4.1)$ & $18 \quad(4.2)$ \\
\hline Yukon & 0 & 0 & 0 & $15 \quad(0.2)$ & $3(0.2)$ & $3 \quad(0.9)$ & $15 \quad(0.2)$ & $3 \quad(0.2)$ & $3 \quad(0.7)$ \\
\hline $\begin{array}{l}\text { Northwest } \\
\text { Territories }\end{array}$ & $6 \quad(0.4)$ & 0 & 0 & $46 \quad(0.6)$ & $7 \quad(0.6)$ & $1 \quad(0.3)$ & $52(0.6)$ & $7 \quad(0.5)$ & $1 \quad(0.2)$ \\
\hline Nunavut & $76 \quad(5.1)$ & $6 \quad(2.1)$ & 1 (1.3) & $9 \quad(0.1)$ & 0 & 0 & $85 \quad(1.0)$ & $6 \quad(0.4)$ & $1 \quad(0.2)$ \\
\hline
\end{tabular}


nant (18.6\% of those admitted to hospital, $9.4 \%$ of those admitted to ICU and none of those who died).

Compared with women of child-bearing age admitted to hospital, pregnant women were slightly younger (median age 28 v. 30 years) and reported underlying medical conditions less frequently. The most commonly reported conditions in pregnant women were chronic pulmonary disease (including asthma) and diabetes.

For the duration of the pandemic, trimester data were available for $50.4 \%$ of the pregnant women admitted to hospital; $61.2 \%$ of them were in the third trimester. Four deaths among pregnant women were reported in the first wave, and none in the second wave. The four deaths involved women between 17 and 24 years of age who were in their third trimester; two of the women were of Aboriginal origin, and none had an underlying medical condition.

\section{Aboriginal people}

During the first pandemic wave, 299 hospital admissions involving patients of Aboriginal origin (188 First Nations, 89 Inuit, 17 Métis and 5 of unknown Aboriginal ethnicity) were reported in Canada (excluding Ontario and Nova Scotia because they did not report on Aboriginal status). During the second wave and the post-peak period, 308 Aboriginal people were admitted to hospital (245 First Nations, 23 Inuit, 31 Métis and 9 of unknown Aboriginal ethnicity). The propor-

Table 3: Incidence of laboratory-confirmed pandemic (H1N1) influenza in Canada during the first wave (Apr. 12 to Aug. 29, 2009) and the second wave and post-peak period (Aug. 30, 2009, to Apr. 3, 2010) of the 2009 pandemic

\begin{tabular}{|c|c|c|c|c|c|c|c|c|c|c|}
\hline \multirow{2}{*}{ Characteristic } & \multirow{2}{*}{ Population } & \multicolumn{8}{|c|}{ Outcome; incidence per 100000 population } & \\
\hline & & \multicolumn{3}{|c|}{ First wave } & \multicolumn{3}{|c|}{$\begin{array}{c}\text { Second wave } \\
\text { and post-peak period }\end{array}$} & \multicolumn{3}{|c|}{ Total } \\
\hline \multicolumn{11}{|l|}{ Age, yr } \\
\hline $1-4$ & 1460882 & 13.1 & 1.3 & 0.0 & 70.7 & 3.8 & $0.2^{*}$ & 83.7 & 5.1 & $0.2^{*}$ \\
\hline $5-19$ & 6026007 & 6.1 & 0.7 & $0.1 *$ & 22.7 & 1.9 & 0.2 & 28.9 & 2.7 & 0.4 \\
\hline 20-44 & 11718791 & 3.2 & 0.8 & 0.2 & 13.6 & 2.8 & 0.6 & 16.8 & 3.6 & 0.8 \\
\hline $45-64$ & 9469891 & 3.3 & 1.0 & 0.3 & 21.0 & 5.4 & 1.7 & 24.2 & 6.4 & 2.0 \\
\hline$\geq 65$ & 4687446 & 2.5 & 0.6 & 0.4 & 15.2 & 3.0 & 1.9 & 17.7 & 3.6 & 2.4 \\
\hline \multicolumn{11}{|l|}{$\begin{array}{l}\text { Provincel } \\
\text { territory }\end{array}$} \\
\hline $\begin{array}{l}\text { British } \\
\text { Columbia }\end{array}$ & 4455207 & 1.1 & 0.4 & $0.1 *$ & 23.2 & 3.3 & 1.2 & 24.3 & 3.8 & 1.3 \\
\hline Alberta & 3687662 & 3.5 & 0.8 & $0.2^{*}$ & 31.1 & 5.7 & 1.7 & 34.6 & 6.5 & 1.9 \\
\hline Saskatchewan & 1030129 & 2.2 & 1.2 & $0.4^{*}$ & 4.3 & 3.9 & 1.1 & 6.5 & 5.0 & 1.5 \\
\hline Manitoba & 1221964 & 17.4 & 3.5 & $0.6^{*}$ & 13.6 & 1.5 & $0.3^{*}$ & 31.0 & 5.0 & 0.9 \\
\hline Ontario & 13069182 & 3.1 & 0.5 & 0.2 & 11.0 & 1.9 & 0.8 & 14.1 & 2.4 & 1.0 \\
\hline Quebec & 7828879 & 7.3 & 1.3 & 0.3 & 31.8 & 4.6 & 1.0 & 39.1 & 5.9 & 1.4 \\
\hline $\begin{array}{l}\text { Northwest } \\
\text { Territories }\end{array}$ & 43439 & $13.8^{*}$ & 0.0 & 0.0 & 105.9 & $16.1^{*}$ & $2.3^{*}$ & 119.7 & 16.1 * & $2.3^{*}$ \\
\hline Nunavut & 32183 & 236.1 & $18.6^{*}$ & $3.1^{*}$ & 28.0 & 0.0 & 0.0 & 264.1 & $18.6 *$ & 3.1 * \\
\hline Total & 33739859 & 4.4 & 0.9 & 0.2 & 21.3 & 3.5 & 1.0 & 25.7 & 4.4 & 1.3 \\
\hline
\end{tabular}

Note: ICU = intensive care unit.

* Rates should be interpreted with caution because of small numbers reported in the given category. 
tion of hospital admissions and deaths involving Aboriginal people decreased from the first wave to the second wave (from $27.8 \%$ to $6.1 \%$ of hospital admissions, and from $17.6 \%$ to $8.9 \%$ of deaths) (Table 2).

The demographic and clinical characteristics of the Aboriginal people admitted to hospital differed between the two pandemic waves. Whereas Inuit accounted for nearly one-third of the Aboriginal patients in the first wave, they represented 7.5\% of them in the second wave. As well, in the first wave, most Aboriginal patients were from Manitoba (46\%) and Nunavut (25\%), and they were young (median age 11.0 years). In the second wave, hospital admissions involving Aboriginal people were reported from 10 provinces and territories, although mainly from Alberta (48\%), and the median age was higher (median age 26 years). In addition, the proportion of Aboriginal patients who had underlying medical conditions was higher and the proportion of women of child-bearing age who were pregnant was lower in the second wave than in the first wave.

\section{Interpretation}

Canada experienced two distinct and relatively different waves of pandemic (H1N1) influenza during the 2009 pandemic. The first was in spring and early summer, when influenza transmission is typically minimal, and the second was earlier in fall than usual. The first wave affected mainly Saskatchewan, Manitoba, Quebec, the Northwest Territories and Nunavut. However, in the second wave, transmission spread rapidly across the country, with nearly all provinces and territories experiencing their peak activity within a threeweek period, as compared with an average peak period of nine weeks during the last 15 influenza seasons. The second wave was substantially larger than the first, with 4.8 times more hospital admissions and 4.6 times more deaths.

Whereas the rate of hospital admission increased in all age groups in the second wave, the largest increase occurred among those 45-64 years of age and the smallest among school-aged children 5-19 years of age. This pattern is consistent with the pattern of influenza transmission in communities from schoolaged children to older populations. ${ }^{47}$ Not unexpectedly, the increased median age among patients admitted to hospital in the second wave was associated with a higher proportion of them having at least one underlying medical condition. However, given these increases, it is surprising that Canada experienced a relative decline in severity among patients admitted to hospital between the first and second pandemic waves.

Pregnant women were overrepresented among the patients admitted to hospital in both pandemic waves: they accounted for $3.1 \%$ of hospital admissions during the pandemic and only $1.0 \%-1.5 \%$ of the general population. Aboriginal people were also disproportionally affected, accounting for $10.0 \%$ of the patients admitted to hospital and only $4.6 \%$ of the general population in the provinces and territories reporting on Aboriginal status. However, the relative proportion of pregnant women and Aboriginal people decreased considerably from the first to the second wave. A number of factors may have contributed to these improvements: an increased awareness among clinicians and the public about groups at risk of pan- demic (H1N1) influenza and about clinical signs associated with severe outcomes; increased and earlier use of antiviral treatment, earlier admission to hospital and specialized care; and targeted interventions for populations living in remote and isolated communities, such as easy and prompt access to antiviral agents. The mass vaccination campaign, which began from Oct. 22 to Nov. 1, 2009, across the country, may also have played a role.

The epidemiologic features of the hospital admissions and deaths reported in Canada are similar to those reported in many other countries in terms of demographic characteristics $^{8-11}$ and most at-risk populations, particularly with regard to underlying conditions, ${ }^{8-15}$ pregnant women ${ }^{9,16,17}$ and indigenous populations. ${ }^{12,17-20}$ The proportion of patients admitted to hospital who had severe outcomes is consistent with proportions reported in other countries (ranging from 12\% to 20\%). ${ }^{21}$ The burden of death associated with pandemic (H1N1) influenza varied considerably across continents and hemispheres, especially where only one winter wave occurred. For example, North American countries reported higher rates of death (Canada 1.3 per 100000 , Mexico 1.2 per $100000^{22}$ and United States an estimated 3.96 per $100000^{23}$ ) than some countries in Europe (e.g., United Kingdom 0.77 per $100000^{24}$ ). Although the cumulative mortality in Canada was higher than the mortality reported in Australia ( 0.93 per $\left.100000^{25}\right)$ and Chile $\left(0.92\right.$ per $\left.100000^{26}\right)$, the rates in those two countries were similar to the rate observed during the winter wave in Canada (1.1 per 100 000).

Besides the variation in attack rates among the different regions of the world and the age groups (and consequently health status) of the population most affected, differences in surveillance systems, particularly case ascertainment and definitions, likely explain some of the disparities observed. Finally, when more accurate assessment of the mortality burden and risk are available, these disparities may change. ${ }^{27}$

\section{Limitations}

Although a standardized surveillance system was established at the national level, there were some differences in case detection among the provinces and territories. Also, as for most population-based surveillance systems, a certain degree of underreporting probably occurred. The degree of completeness of data was a challenge for underlying conditions ( $57 \%$ complete) and Aboriginal origin ( $62 \%$ complete). The number of patients of Aboriginal origin reported in this analysis represents an underestimate, because Aboriginal status is self-reported in many jurisdictions and two provinces did not report on this variable. Finally, certain detailed variables may have been incompletely captured or collected only for severe cases.

\section{Conclusion}

The second wave of pandemic (H1N1) 2009 in Canada was substantially greater than the first. The proportion of severe cases (ICU admissions and deaths) was lower in the second wave than in the first, even though patients in the second wave were older and more had an underlying medical condition. Although pregnant women and Aboriginal people were still at increased risk of severe disease in the second wave, 
they made up proportionally fewer of all hospital admissions and deaths in the second wave than in the first.

These differences are thought to be due mainly to public health and clinical interventions implemented between the first and second waves. Although the epidemiologic features of the hospital admissions reported in Canada is quite similar to what occurred in many other countries in terms of groups at risk, the mortality burden due to pandemic (H1N1) influenza in Canada appears to be higher than in many countries to date.

A national seroprevalence survey at the end of the first wave would have allowed us to better qualify the severity of the cases in Canada and permitted a more accurate comparison with other countries.

\section{This article has been peer reviewed.}

\section{Competing interests: None declared.}

Contributors: All of the authors contributed to the study design and interpretation of data. Melissa Helferty, Julie Vachon and Louise Pelletier drafted the original manuscript. All of the authors critically revised the manuscript for intellectual content and approved the final version submitted for publication.

Acknowledgements: The authors thank the provincial and territorial influenza surveillance teams for their dedication in collecting and reporting data to the Public Health Agency of Canada throughout the pandemic. They also thank all members of the Pandemic H1N1 2009 Surveillance and Epidemiology Laboratory Task Group for their expertise and input.

Funding: No funding was received for this study.

\section{REFERENCES}

1. Cutler J, Schleihauf E, Hatchette TF, et al. Investigation of the first cases of human-to-human infection with the new swine-origin influenza A (H1N1) virus in Canada. CMAJ 2009;181:159-63.

2. Public Health Agency of Canada. Case definitions for national surveillance HINI flu virus. H1N1 flu virus: information for health professionals. Ottawa (ON): The Agency; 2009. Available: www.phac-aspc.gc.ca/alert-alerte/h1n1/hp-ps-info _definition-eng.php (accessed 2009 May 11).

3. Canada's population estimates: age and sex, July 1, 2009. The Daily [Statistics Canada] 2009 Nov. 27: Tables 1 and 2. Available: www.statcan.gc.ca/dailyquotidien/091127/dq091127b-eng.htm (accessed 2010 Jan. 9).

4. Weycker D, Edelsberg J, Halloran ME, et al. Population-wide benefits of routine vaccination of children against influenza. Vaccine 2005;23:1284-93.

5. Longini IM Jr, Halloran ME. Strategy for distribution of influenza vaccine to highrisk groups and children. Am J Epidemiol 2005;161:303-6.

6. Glass LM, Glass RJ. Social contact networks for the spread of pandemic influenza in children and teenagers. BMC Public Health 2008;8:61.

7. Loeb M, Russell M, Moss L, et al. Effect of influenza vaccination of children on infection rates in Hutterite communities. JAMA 2010;303:943-50.

8. European Centre for Disease Prevention and Control. ECDC risk assessment: pandemic H1N1 2009. Version 7. Stockholm (Sweden); The Centre; 2009.

9. The Health Protection Agency. Pandemic (H1N1) 2009 in England: an overview of initial epidemiological findings and implications for the second wave. London (UK): The Agency; 2009.

10. US Center for Disease Control and Prevention. Update: influenza activity United States, August 30-October 31, 2009. MMWR Morb Mortal Wkly Rep 2009; 58:1236-41

11. van 't Klooster TM, Wielders CC, Donker T, et al. Surveillance of hospitalizations for 2009 pandemic influenza A (H1N1) in the Netherlands, June 5-December 31 2009. Euro Surveill 2010;15:pii:19461.

12. Kumar A, Zarychanski R, Pinto R, et al. Critically ill patients with 2009 influneza A (H1N1) infection in Canada. JAMA 2009;302:1872-9.

13. Chowell G, Bertozzi SM, Colchero MA, et al. Severe respiratory disease concurrent with the circulation of H1N1 influenza. N Engl J Med 2009;361:674-9.

14. Fuhrman C, Bonmarin I, Paty AC, et al. Severe hospitalized 2009 pandemic influenza A(H1N1) cases in France, 1 July-15 November 2009. Euro Surveill 2010;15:pii: 19463.

15. Louie JK, Acosta M, Winter K, et al. Factors associated with death or hospitalization due to pandemic 2009 influenza $\mathrm{A}(\mathrm{H} 1 \mathrm{~N} 1)$ infection in California. JAMA 2009;302:1896-902.

16. Kelly H, Mercer GN, Cheng AC. Quantifying the risk of pandemic influenza in pregnancy and Indigenous people in Australia in 2009. Euro Surveill 2009;14:pii: 19441.

17. ANZIC Influenza Investigators and Australasian Maternity Outcomes Surveillance System. Critical illness due to $2009 \mathrm{~A} / \mathrm{H} 1 \mathrm{~N} 1$ influenza in pregnant and postpartum women: population based cohort study. BMJ 2010;340:c1279.

18. La Ruche G, Tarantola A, Barboza P, et al. The 2009 pandemic H1N1 influenza and indigenous populations of the Americas and the Pacific. Euro Surveill 2009; 14:pii: 19366

19. Verrall A, Norton K, Rooker S, et al. Hospitalizations for pandemic (H1N1) 2009 in Maori and Pacific Islanders, New Zealand. Emerg Infect Dis 2010;16:100-2.

20. Campbell A, Rodin R, Kropp R, et al. Risk of severe outcomes among patients admitted to hospital with pandemic (H1N1) influenza. CMAJ 2010;182:349-55.

21. US Center for Disease Control and Prevention. Deaths related to 2009 pandemic influenza A (H1N1) among American Indian/Alaska Natives - 12 States. MMWR Morb Mortal Wkly Rep 2009;58:1341-4.

22. Situación actual de la epidemia, 05 de Julio2010. Cuauhtémoc (Mexico): Secretaria de Salud, Mexico; 2010

23. The 2009 H1N1 pandemic: summary highlights, April 2009-April 2010. Atlanta (GA): US Centers for Disease Control and Prevention; 2009.

24. HPA weekly national influenza report - summary of UK surveillance of influenza and other seasonal respiratory illnesses. London (UK): UK Health Protection Agency; 2010

25. Australian influenza surveillance report. Canberra (Australia): Australian Government - Department of Health and Ageing; 2010.

26. Reporte Situacion 30 de Junio de 2010 - Influenza pandemica (H1N1) 2009. Santiago (Chile): Ministerio de la Salud de Chile; 2010.

27. Comparing deaths from pandemic and seasonal influenza: pandemic (H1N1) 2009. Briefing note 20. Geneva (Switzerland): World Health Organization; 2009.

Correspondence to: Melissa Helferty, Public Health Agency of Canada, Rm. 5902A, 380 Hunt Club Rd., Ottawa ON K1V 1C1; melissa_helferty@phac-aspc.gc.ca

\section{Atacand}

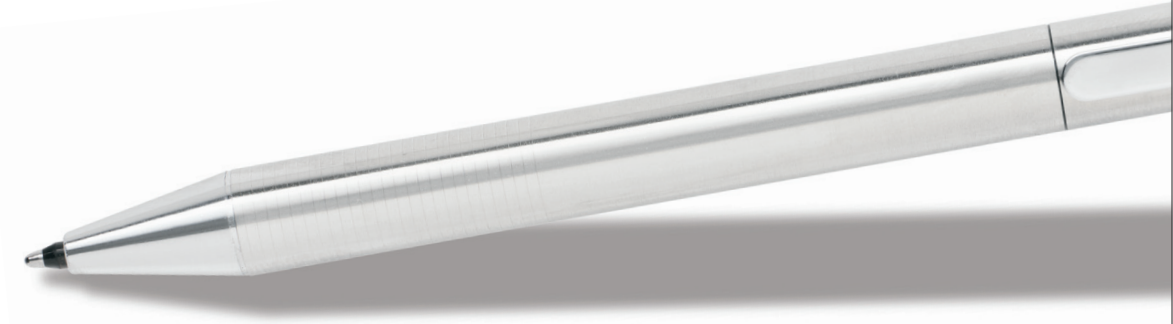

